\title{
Relevance of the mineralogical characterisation of serpentinites for their use as dimension stone: an example from Galicia, Spain
}

\author{
${ }^{1}$ Department of Geology, University of Salamanca, Avd. Requejo 33, 49022 Zamora, Spain \\ ${ }^{2}$ CHARROCK Research Group. University of Salamanca, Plaza de los Caídos s/n, 37008 Salamanca, Spain; *Corresponding author, \\ E-mail:mdp@usal.es \\ ${ }^{3}$ Department of Geology, University of Salamanca, Plaza de los Caídos s/n, 37008, Salamanca, Spain
}

(Received: January 31, 2020; Revised accepted: April 18, 2020)

https://doi.org/10.18814/epiiugs/2020/0200s04

Workers carrying out actions involving potential hazards, like mining and quarrying, can be subject to health issues derived from those activities. The case of asbestosis has generated an alarm in the society. Natural stones are very different from each other and generalisation can cause, first an unwanted alarm, and secondly a big economic crisis in the sector of the natural stone, as it has happened before with other health issues related to exploitation and use of natural stone in architecture. This paper highlights the need for an appropriate mineralogical characterization of rocks of economic interest, such as serpentinites, to protect mining workers of health issues derived from fibrous minerals content. We have studied the possible presence of fibrous minerals in samples of serpentinites from an abandoned quarry in Galicia (North Western Spain) to consider the viability of its re-opening based on the Spanish health and safety regulations applicable to jobs at risk of exposure to asbestos. From our study, it can be concluded that there is a scarce amount of fibrous phases, pending on further studies to differentiate such fibrous minerals, and therefore the reopening of the serpentinite quarry should not be a health problem for the workers.

\section{Introduction}

Governments at international level are increasingly aware about the health issues that some activities may cause to workers who carry out actions involving some potential hazards. Over the last years, the case of asbestos pollution has generated an alarm in the society. This issue is of great importance, but it has also shown the lack of scientific culture in society. The same can be applied to some other issues, such as that of natural radioactivity in rocks (Pereira et al., 2011), which had to be explained with clear objectivity and in layman's terms to make people understand that these natural characteristics of rocks have to be studied, described and reflected by professionals on a case-by-case basis. Rocks are very different from each other and generalisation can cause, first an unwanted alarm, and secondly a big economic crisis in the sector of the natural stone, as it already happened with misleading news related to Rn emission and granite countertops (Natural Stone Institute, 2014). The same could happen with rocks that may contain fibrous minerals.

Asbestos (also called amianto in Spanish) is a commercial term for a group of minerals whose crystals have a fibrous form with a certain degree of flexibility. The six minerals commonly referred to as asbestos belong to two distinctive groups of minerals: serpentine (chrysotile or white asbestos) and amphibole (amosite or brown asbestos; crocidolite or blue asbestos; anthophyllite; tremolite; and actinolite) (Bernstein, 2009). Asbestosis is a long-term inflammation and scarring of the lungs, produced by the inhalation of microscopic mineral fibres, known as asbestos (Sporn et al., 2004). Those fibers may be suspended in the air and the atmosphere surrounding some working activities related to mining, and other activities such as textile industry, construction, etc. Symptoms of asbestosis (e.g., shortness of breath, cough, wheezing, chest tightness, etc.) are typically manifested after exposure to asbestos (NHS Inform, 2017). Generally, the development of the disease requires a large exposure to these fibres over a long period of time. Complications of asbestosis may include lung cancer, mesothelioma and pulmonary heart disease. The main problem is that currently there is no cure for it (International Agency for Research on Cancer, IARC, 2012).

Due to proven health problems arising from the inhalation of its fibres, its use, commercialisation and distribution is prohibited or limited in many countries. In the case of the European Union, since the Directive 1999/77/CE of July 26, 1999 was established; EC Directive 1999/ 77/CE 26 July 1999, that represents the sixth upgrade of annex I to the EC Directive 76/769/CEE ruling the of legislative, dispositive and administrative harmonization of Member states on the input on the market and use of some hazardous substances, including asbestos. In Spain, the Real Decreto 396/2006, of March 31, established the minimum health and safety regulations applicable to jobs at risk of exposure to asbestos. In that document, the maximum limit of environmental exposure per day to all varieties of asbestos is $0.1 \mathrm{fibres} / \mathrm{cm}^{3}$. According to the World Health Organization (WHO) minerals are considered as asbestos when the length is up to $5 \mu \mathrm{m}$ and the length divided by width is up to 3:1 (WHO 1986, Directive 2003/18/EC, NIOSH 2008), although 
fibres with higher length or lower width can be dangerous as well (Bloise et al., 2014 and references therein).

Laws for restriction and control of activities where asbestos is used refer mainly to those activities where it was deliberately added to change the composition of the original material in order to, for example, increase the resistance: thermic insulation, acoustic insulation, fire retardant capacity, etc. However, they rarely refer to the appearance of the original asbestos source: the natural stone.

Serpentinites are commonly used as raw materials for the production of high-purity magnesium oxide, construction aggregates, ornamental stones and, of course, exploitation of asbestiform minerals. Within this group of minerals, chrysotile is the most common variety of asbestos, used as an additive to change the referred characteristics. The use of chrysotile is above $90 \%$ of the total commonly used asbestos (INSHT, 2008).

The physical and mechanical behaviour of these rocks seems to depend on the serpentine phase that is predominant in their composition (Pereira et al., 2013) or on the degree of carbonation (Navarro et al., 2018), although sometimes it is not easy to identify them by petrographic traditional methods. Therefore, the correct use of serpentinites depends upon the mineralogical composition. A specific analysis of the mineralogy of these rocks can greatly improve their use in industry.

The difficulties of extracting blocks without breaking them, the lack of appropriate characterisation and the heterogeneity of the rock even in the same outcrop -regarding both mineralogy and structureshave led to the closure of traditional quarries. However, the aesthetic value of this stone is moving some companies to investigate the potential of reopening the quarries if a new technology to enhance the physical and mechanical characteristics of these rocks was applied (LópezBuendía et al., 2013).

For this reason, a study on the asbestos content in these stones, as well as its dispersion by natural or anthropic factors, may serve as a prevention measure in case the stone sector decided favourably on the possible extraction of the rocks for their use as dimension stones. Naturally Occurring Asbestos (NOA) should be quantified before making any decision about opening, or re-opening, a quarry of serpentinites (Gaggero et al., 2013; Bloise et al., 2017; Puncturo et al., 2019), due to their potential negative effect on the health of the workers. Although accredited laboratories should take care of measuring the quantity of asbestos in the air while the stone is extracted, a preliminary scientific study of the possible content of fibrous minerals is also a good approach before more technical operations take place.

Serpentinites from Galicia have been extracted for centuries, mainly in the areas of Cabo Ortegal complex: Herbeira massif (at present, only for aggregates and iron and steel industry), Somozas and Moeche. These rocks were commercialised as Verde Pirineos (Pereira et al., 2005; Pereira et al., 2007). Small quarries produced the stone until these quarries, some of which were family-run local businesses, closed the activity.

Many monuments, buildings and sites of cultural heritage importance in this part of Spain were built with serpentinites and with its totally transformed into talc and carbonates variety, locally known as "Pedra de Toelo" (Nespereira et al., 2019). Today it is also used with decorative purposes in sculptures, fountains, crosses and lintels (Figs. 1 and 2) (Burgoa-Fernandez, 2000).

The origin of this paper rests on the request of a multinational com-

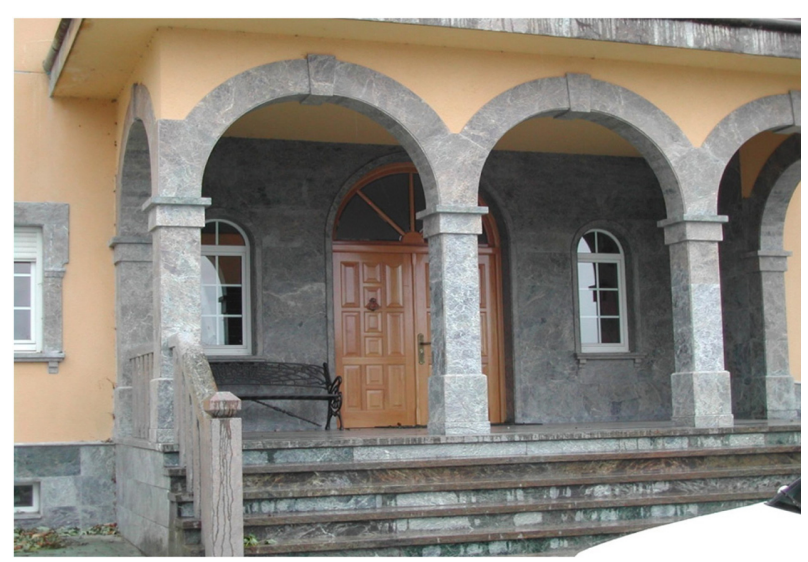

Figure 1. Stairs and lintels made of serpentinites from Galicia at the entrance of the town hall of the village of San Ramón de Moeche (A Coruña).

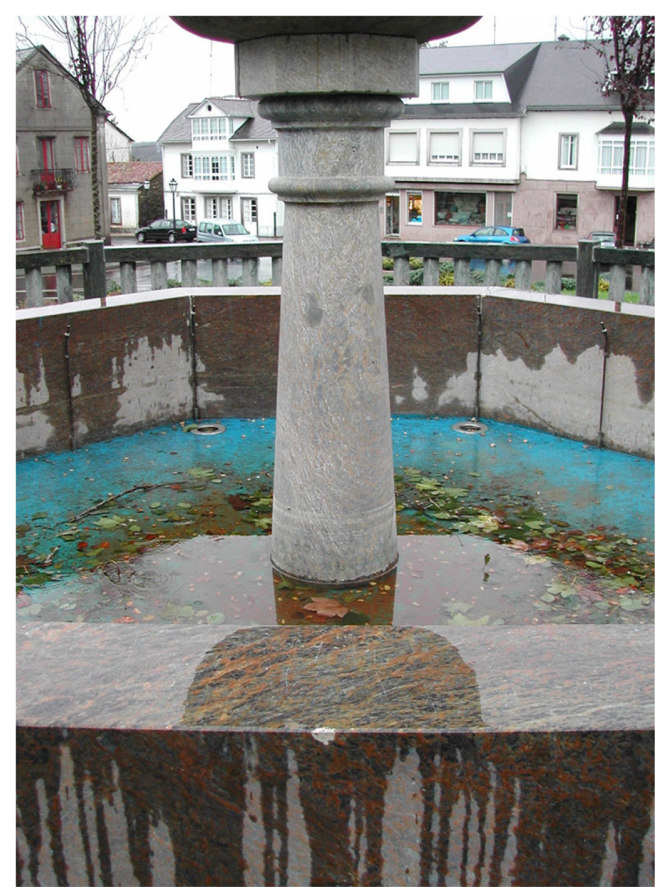

Figure 2. Fountain in the main square in the village of San Ramón de Moeche, (A Coruña), made of serpentinites from Galicia.

pany extracting and commercializing natural stone that was interested in knowing if the serpentinites from Galicia have a lot of fibrous minerals. In this paper we report the results of a study focused on the mineralogical characterisation of serpentinites from an abandoned quarry in Moeche, Spain, once used for construction and heritage architecture in the area, in order to evaluate the possibilities for safe re-opening. It is not our aim to distinguish among the different fibrous phases, although we think that this will be important as a further step on the characterization of these rocks.

\section{Location and Geological Setting}

The studied samples were collected in a large abandoned quarry in the area of Moeche (A Coruña, NW of Spain), in a place known as Monte 

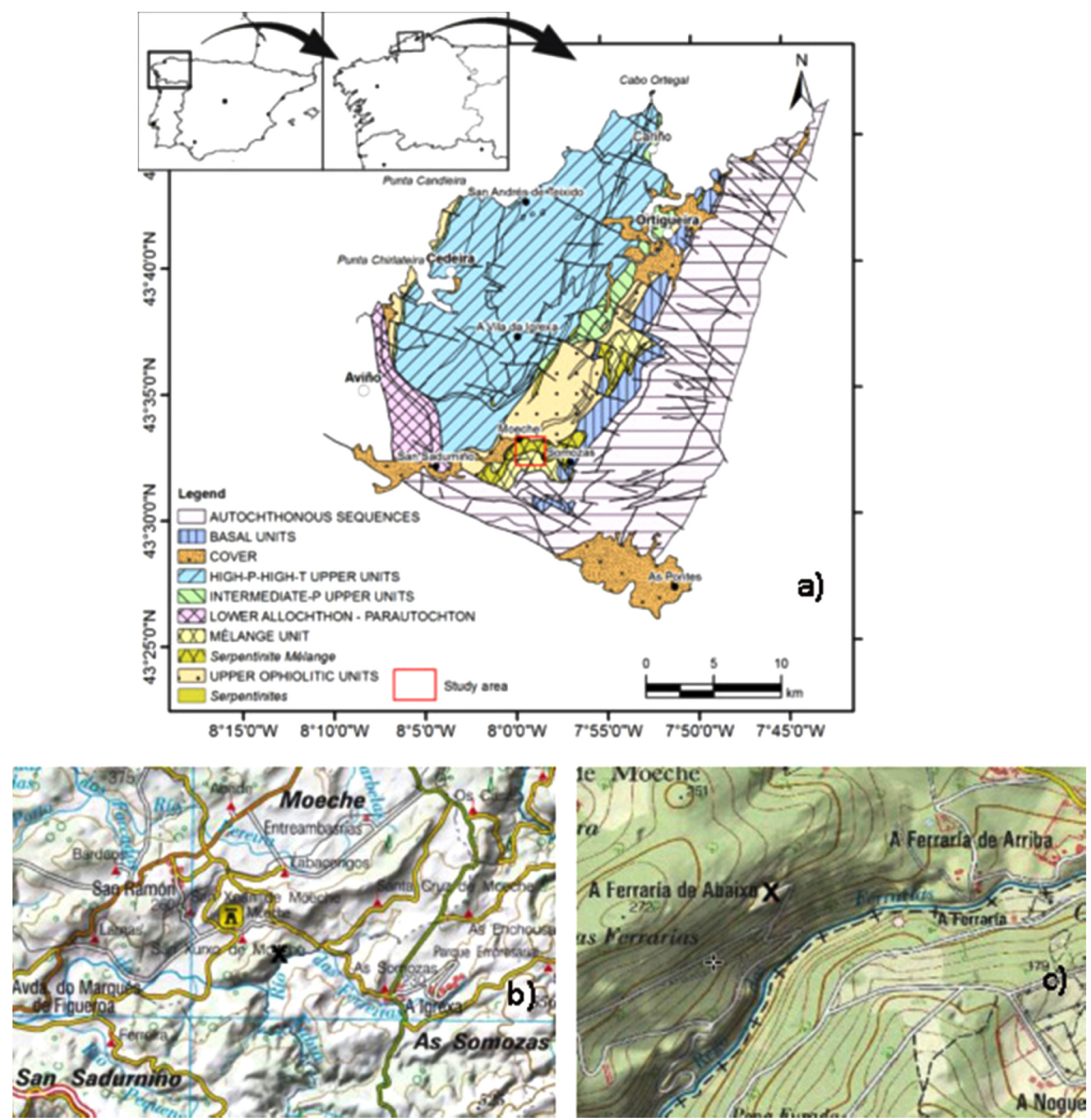

Figure 3. a) Geological setting of the Cabo Ortegal Complex and location of the studied area (Modified from Martínez-Catalán et al. 2019); b and c) Location of the studied quarry in the topographic map.

as Ferrarías (Fig. 3 and 4).

Geologically, these serpentinites belong to the Cabo Ortegal Complex, one of the five allochthonous complexes of the NW Iberian allochthonous complexes of Galicia-Tras-Os-Montes area (Iberian Massif) (Fig. 3a). These allochthonous units are classified according to their tectonic position in Upper, Middle (or Ophiolitic Unit) or Lower allochthonous. The Ophiolitic units are formed by dismembered slices of true ophiolitic slices and transitional or thinned crust units, which may have been affected locally by high-grade metamorphism (MartínezCatalán et al., 2019). Within this Unit, two sub-units of different age are described: one Cambro-Ordovician and one Early Devonian. The Somozas Mélange, where the serpentinites of this work are located, belongs to the former sub-unit. The Somozas Mélange includes both an ophiolitic and a metasedimentary sequence. At the top, serpentinites appeared as sheared blocks intercalated with igneous rocks (e.g., gabbros, diabases, granitoids and volcanic rocks) and metasediments such as phyllites and phyllonites, with inclusions of sandstones, conglomerates and marbles. The thickness is about $800 \mathrm{~m}$. The bottom part is made up of a mélange of ochre or blue phyllites, with a thickness of $1000 \mathrm{~m}$. High-T metamorphic blocks of amphibolites and orthogneisses are also observed (Arenas et al., 2009).

Serpentinite outcrops in Moeche are elongated, with slightly positive reliefs. The dimensions of these outcrops can be variable, from thin, metric bodies to several kilometres long and several hundred meters of thickness. If fresh, the rock has a deep green colour that can tend to whitish tones when talc is present and brownish shades when carbonate content increases. Locally, in the contact of serpentinites massifs with the host, a complete transformation into talc is produced, 


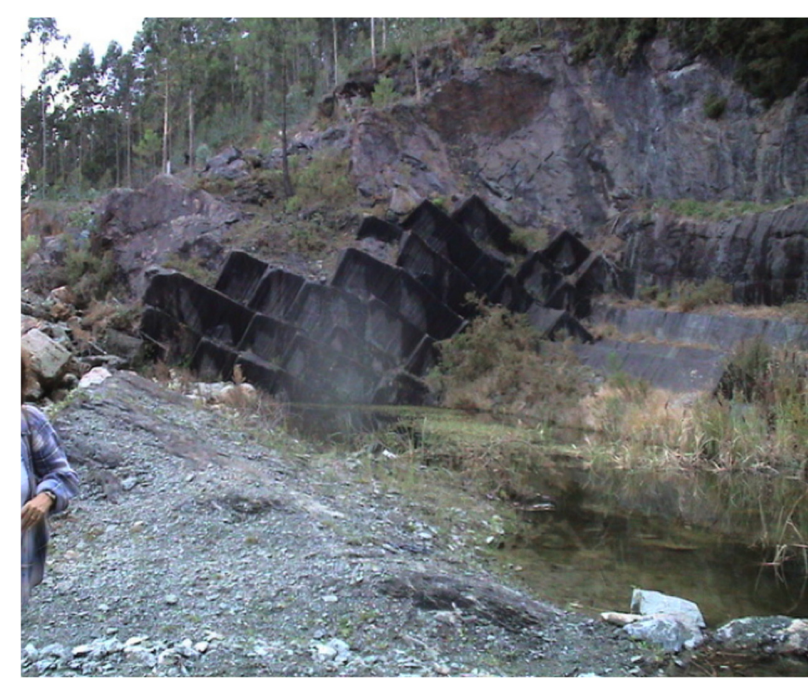

Figure 4. Abandoned quarry of serpentinites in Moeche. Extraction works could be observed in detail. Many abandoned blocks were found in the quarry, which has drawn the attention of the stone sector in terms of reactivating the quarrying activities.
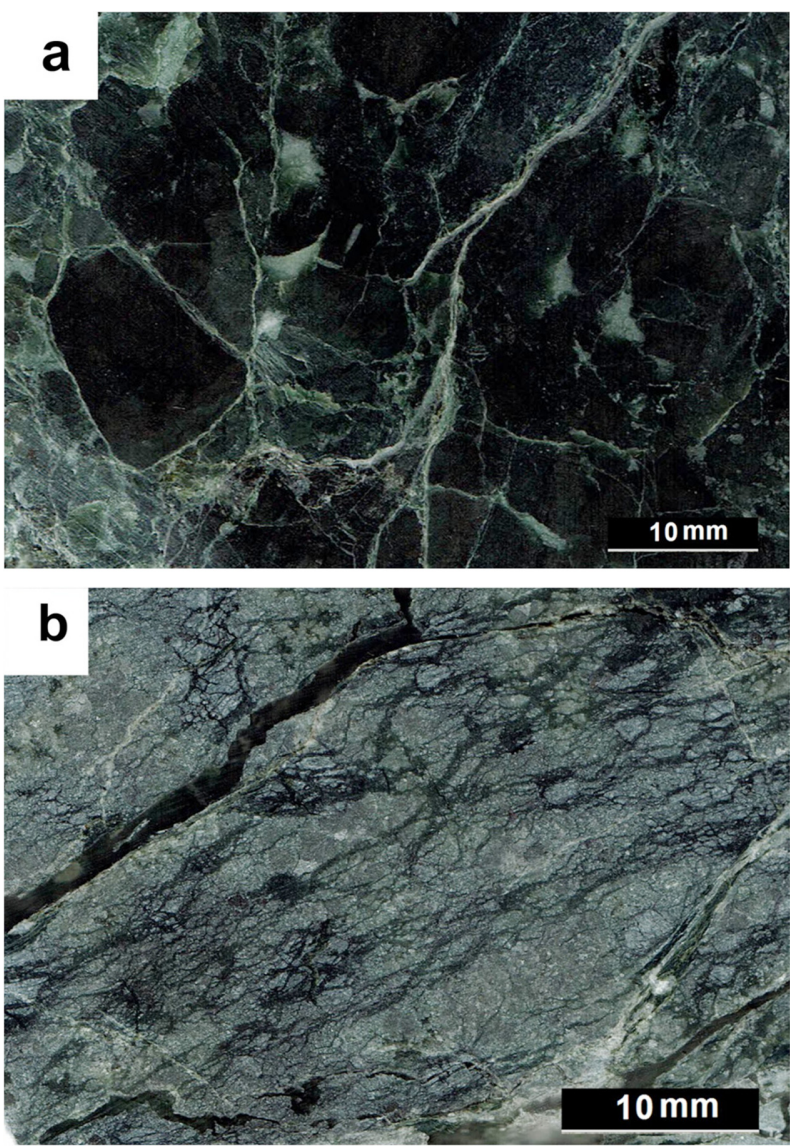

Figure 5. Polished samples were scanned for detailed observations of the variable aspects of serpentinites from Moeche: a) Sample with scarce fracturing and foliation, with nodules not affected by structures, where darker green colour is highlighted; b) Sample intensively fractured and foliated.

giving the variety of stone locally called "Pedra de Toelo" (Nespereira et al., 2019 and references therein). The rocks found go from massive, with only a few fractures with variable directions (Fig. 5a), to intensively foliated rocks as a consequence of the intense deformation periods that affected these massifs (Fig. 5b). However, foliation does not always affect the complete rock, but partially in a way that nodules areas are found, resembling clasts of a more intense green colour (Fig. 5a).

\section{Materials and Methods}

The research group has worked on samples from different quarries from the Moeche area for many years, focussing on different aspects: petrology, petrography, physical and mechanical characterization, etc. Those samples, a set of over thirty specimens, have given a full bibliography that has been used to frame the present work (e.g., Pereira et al., 2007; Pereira et al., 2008; Pereira, 2012; Pereira et al., 2013). For this paper, a selection of ten samples from the abandoned quarry at Monte as Ferrarías (Fig. 3 and 4) were studied in detail, focussing more generally on mineralogy and in particular on the existence of fibrous minerals, without distinction. Fibrous minerals were detected in the field only as part of veins cutting the peridotite and the serpentinites.

Thin sections of the serpentinites samples were studied for their mineralogical analysis using a Leica DM2500P microscope with digital camera.

$\mathrm{X}$-ray powder patterns of the samples were measured at room temperature between 3 and $70{ }^{\circ} \mathrm{C}$ (2-theta) by using a Bruker D8 Advance Eco diffractometer in step-scan mode, $\mathrm{Cu} \mathrm{K} \mathrm{K}_{\alpha}$ radiation $\left(\lambda_{1}=1.54060\right.$ $\AA$ y $\lambda_{2}=1.54439 \AA$ ), a step size of $0.02^{\circ}$, and a time per step of $1.0 \mathrm{~s}$.

Scanning Electron Microscopy (SEM) studies were recorded with a Zeiss EM 900 instrument. Previously, the samples were prepared in aqueous suspension in an ultrasonic bath. See complete procedure at Rivero Crespo et al. (2019).

\section{Results}

\section{Petrography}

From the petrographical study, it was observed that most samples contained serpentine phases as the main mineral component. Some of them were extremely carbonated. The origin of carbonation in each case is being investigated at present through stable isotope analysis and fluorescence microscopy (in prep.). Talc and accessories of magnetite and $\mathrm{Cr}$-spinel are also found in some of the thin sections. Relative proportions of mineral phases can vary, although original, ultramafic mineralogy is mostly absent (except the accessory spinel). Description of minerals follows.

\section{Serpentine}

Serpentine shows variable textures, depending on the original mineral they form from and the recrystallisation degree: pseudomorphic and non-pseudomorphic textures are recognized, the former giving the information on the original mineral phase (Wicks and Wittaker, 1977). The following textures were described in our rocks:

- Mesh texture (Fig. 6). This pseudomorphic texture occurs when 

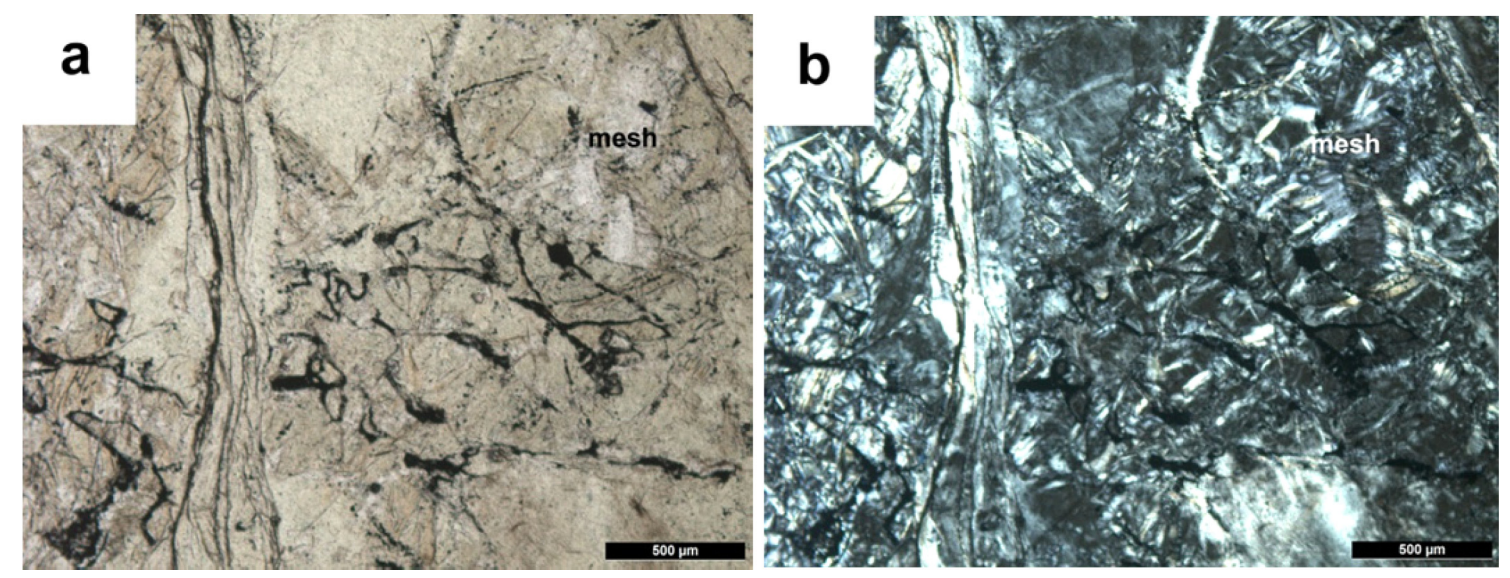

Figure 6. Serpentine showing mesh texture, derived from serpentinisation of olivine. a) parallel nichols; b) crossed nichols. The minerals in the vein seem to be chrysotile, from the petrography observations.
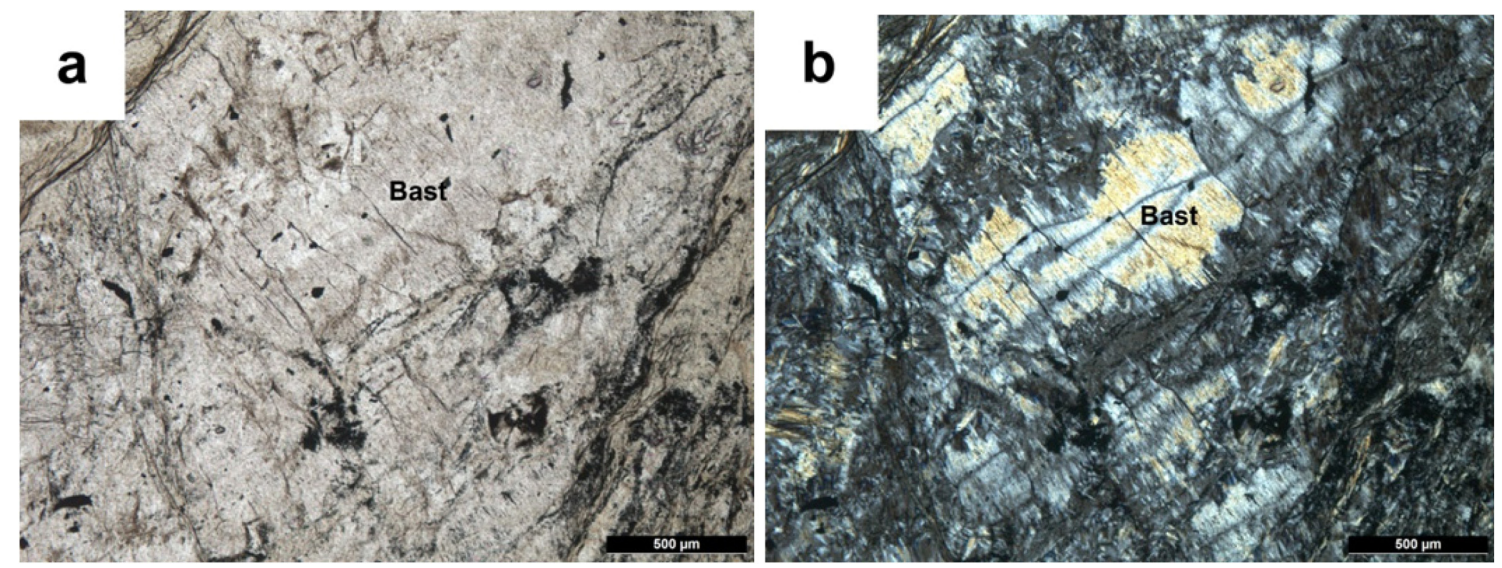

Figure 7. Bastite, serpentine developed from pyroxene serpentinisation. a) parallel nichols; b) crossed nichols.
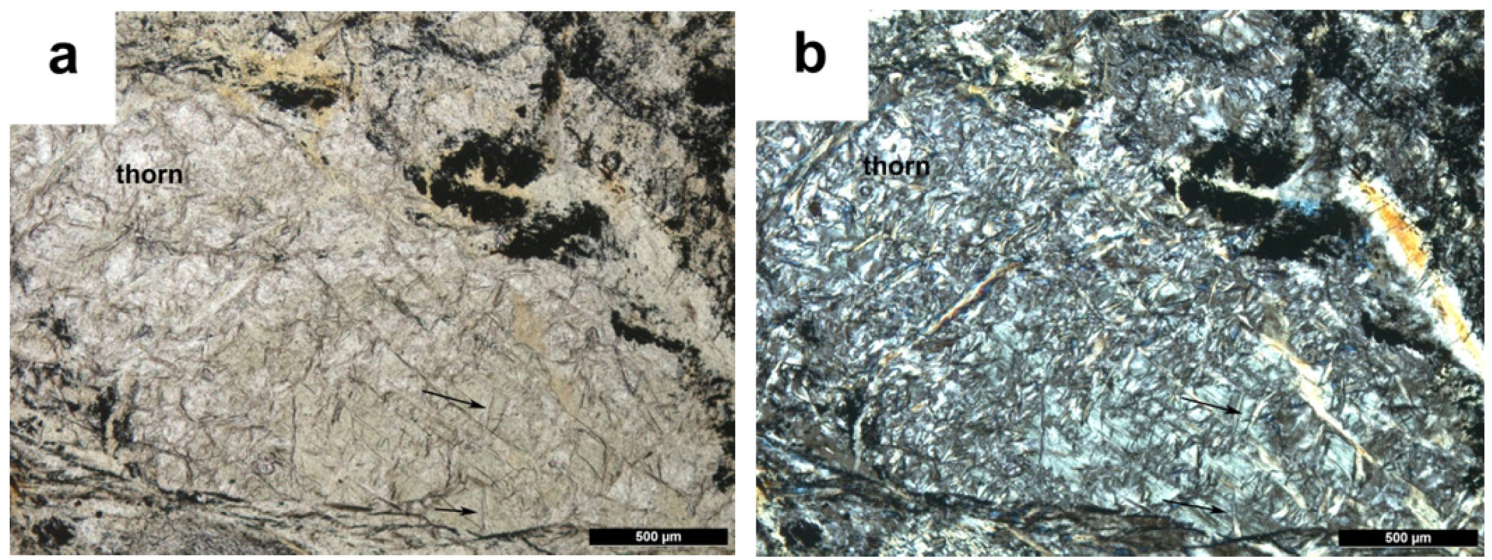

Figure 8. Thorn texture developed from bastite. Massive at the superior left corner; individual crystals are shown by arrows at the bottom right. a) parallel nichols; b) crossed nichols.

serpentinisation takes place following original fractures in olivine (Wicks et al., 1977).

- Bastite porphiroblasts (Fig. 7). Appears as elongated aggregates of serpentine, following previous exfoliation of pyroxenes.

Both, mesh texture and bastite porphiroblasts were always found in lens-shaped areas, not affected by foliation.

- Thorn texture (Fig. 8). Corresponds to a higher recrystallisation degree and it is formed from the other two. In this case, we cannot dis- tinguish the original mineralogy (olivine or pyroxene), although there is a different trend in the orientation of crystals: perpendicular in the case of olivine and parallel for pyroxenes.

- Serpentine veins, mainly slip-fiber veins (Wicks and Wittaker, 1977). Fibrous serpentine, with oriented fibres parallel to sub-parallel to vein walls. The fibres follow the foliation and/or fractures of the rock, defining the frequent foliated aspect of these rocks (Figs. $9,10 \mathrm{a}$ and $10 \mathrm{~b})$. 

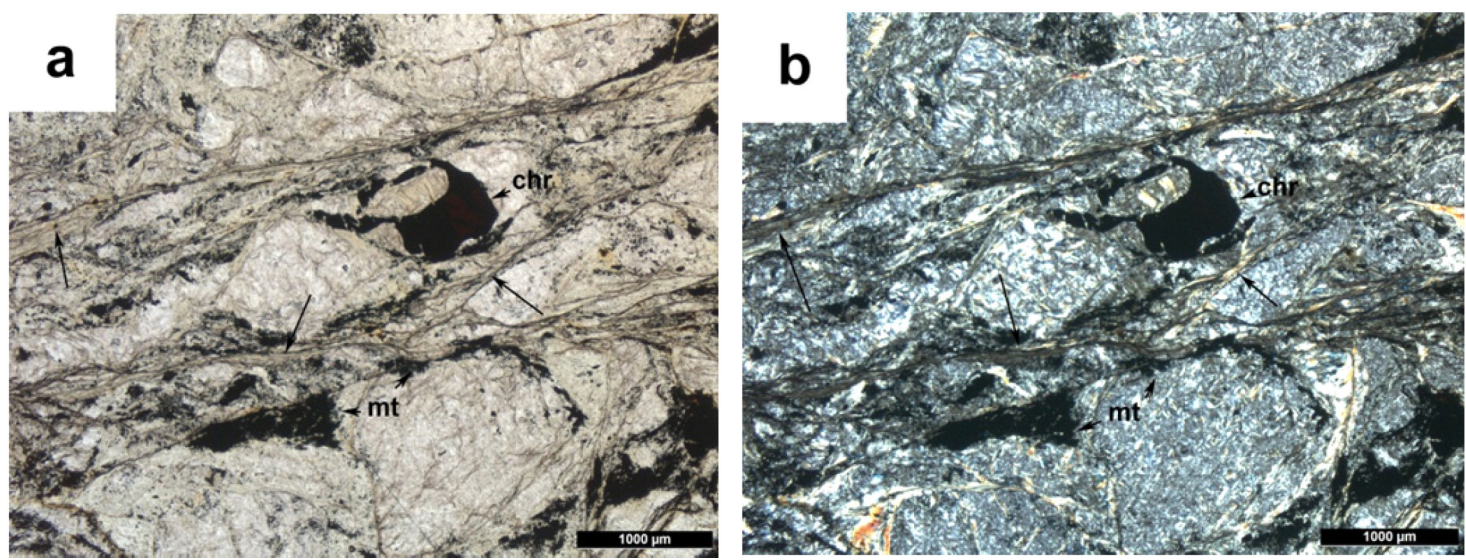

Figure 9. Fibrous serpentine, probably chrysotile, oriented following the foliation of the rock (shown by arrows). Chr: chromium-spinel; mt: magnetite. a) parallel nichols; b) crossed nichols.

\section{Carbonates}

Carbonates appear in a variable amount, mostly as Mg-carbonate. Their most found texture was as crystals lineated along fractures and foliation (Figs. 10a, b), always related to fibrous serpentine. Isolated crystals and aggregates of carbonates were also found in areas that were not affected by foliation of fractures (Fig. 10c). Carbonates in fractures appeared as clean crystals, while isolated crystals or irregular mass of carbonates appeared as cloudy shapes, showing relicts of pre- vious mineralogy (e.g., olivine serpentinisation textures showed in Fig. 10d).

\section{Talc}

Most rocks did not present talc, but in some samples it was the essential phase of the rock. It appeared intergrown and sometimes substituting serpentine. It was also common to find parallel bands of talc and serpentine or talc and carbonates, defining the foliation of the rock (Fig. 10d).
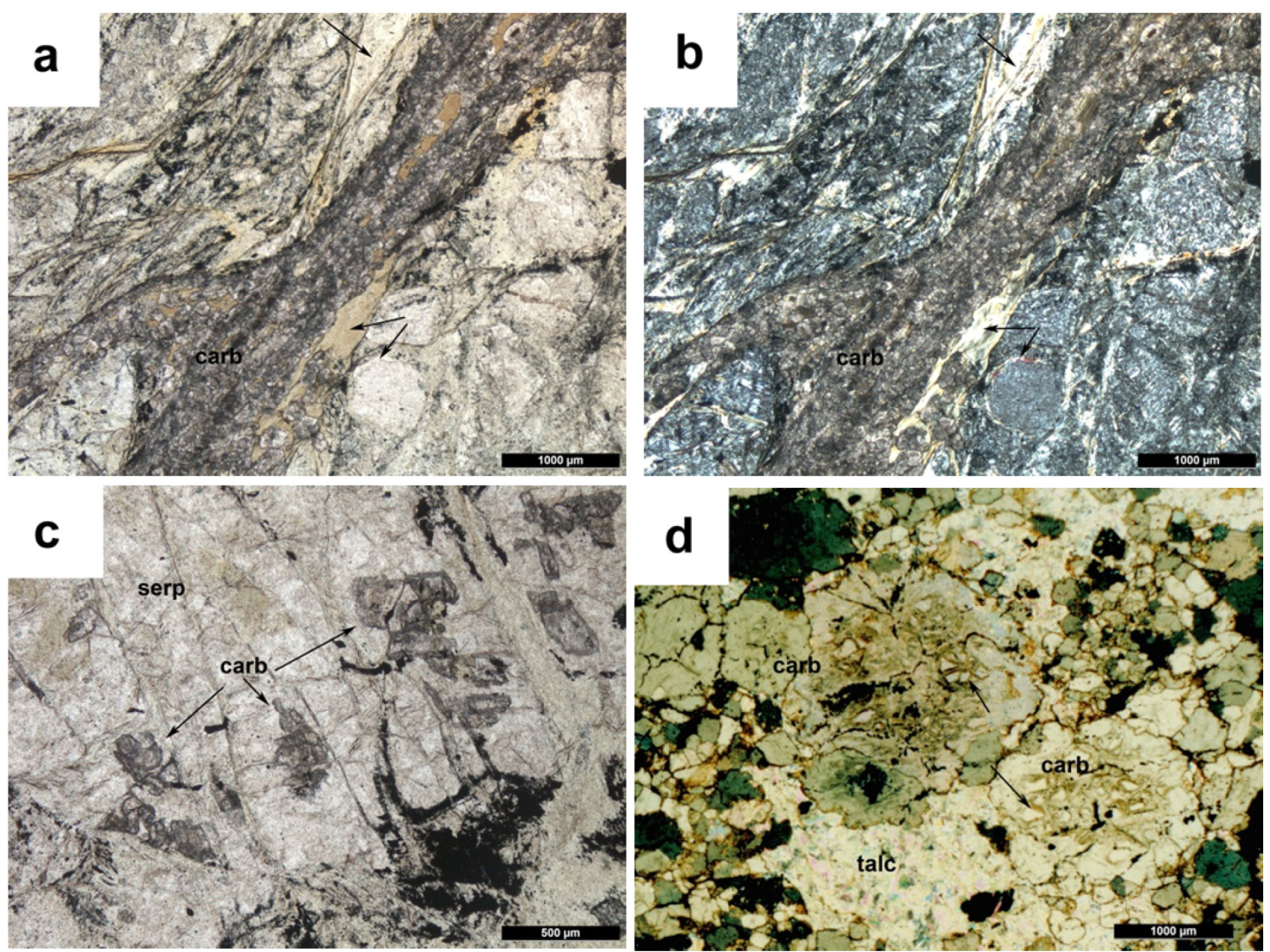

Figure 10. a and b) Carbonates in fracture, associated to fibrous serpentine; a) parallel nichols; b) crossed nichols. c) Carbonates disseminated in a mass of serpentine; parallel nichols. d) Rock made up of talc and carbonates. Previous textures can be recognized, as derived from olivine serpentinisation, previous to carbonation of the rock (arrows). Crossed nichols. 


\section{Accessories}

Magnetite and Cr-spinel were the most frequent accessory minerals. Cr-spinel was the only relict phase from the original mineralogy. It appeared as isolated crystals, with a brown core and irregular borders due to the growth of magnetite (Fig. 9). Magnetite was formed from the liberated iron in the serpentinisation process of iron-rich minerals. It appeared as little opaque crystals disseminated in most samples, either as scarce grains or aggregates (Fig. 9).

\section{X-Ray Diffraction}

The diffraction patterns for the studied serpentinite samples showed characteristic peaks of serpentine-based structures. The predominant polymorph of serpentine in massive serpentinite seems to be antigorite i.e., serpentine originating from the transformation of olivines and
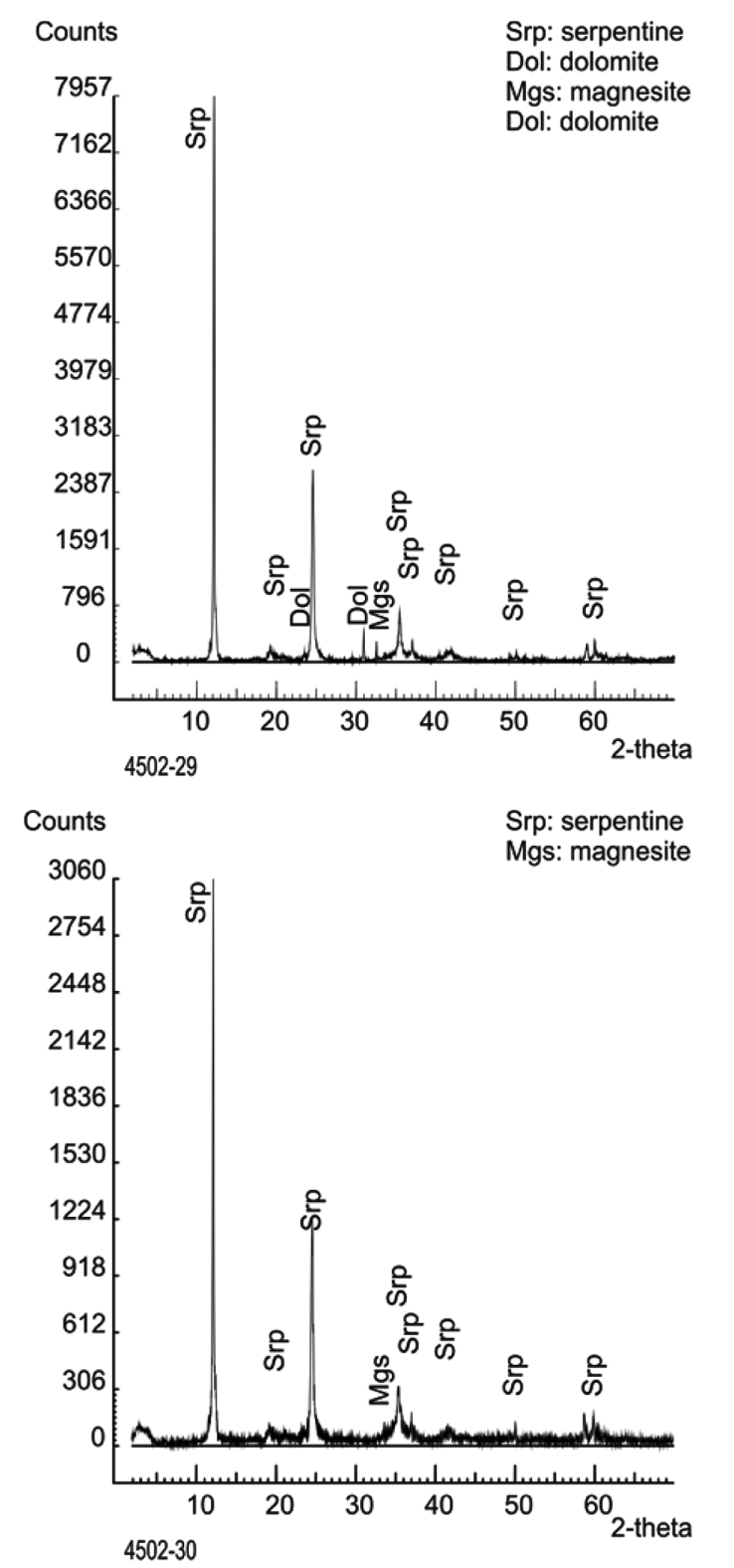

pyroxenes. Detailed information on the structural parameters can be found at Rivero Crespo et al. (2019). However, to differentiate serpentine mineral phases through X-Ray diffraction is very complicated (Fig. 11).

\section{Scanning Electron Microscope}

A previous study on the different serpentine phases of these and other serpentinites samples from Iberia was published in Rivero Crespo et al. (2019) using Scanning Electron Microscope. This work showed that the most common serpentine minerals in the samples from Galicia were antigorite.

SEM showed that antigorite was present as globular morphologies, in contrast with the scarce prismatic shapes that corresponded to lizardite, in agreement with the X-Ray diffraction analysis, and also with the literature data (Wicks and O'Hanley, 1988; Auzende et al., 2002).
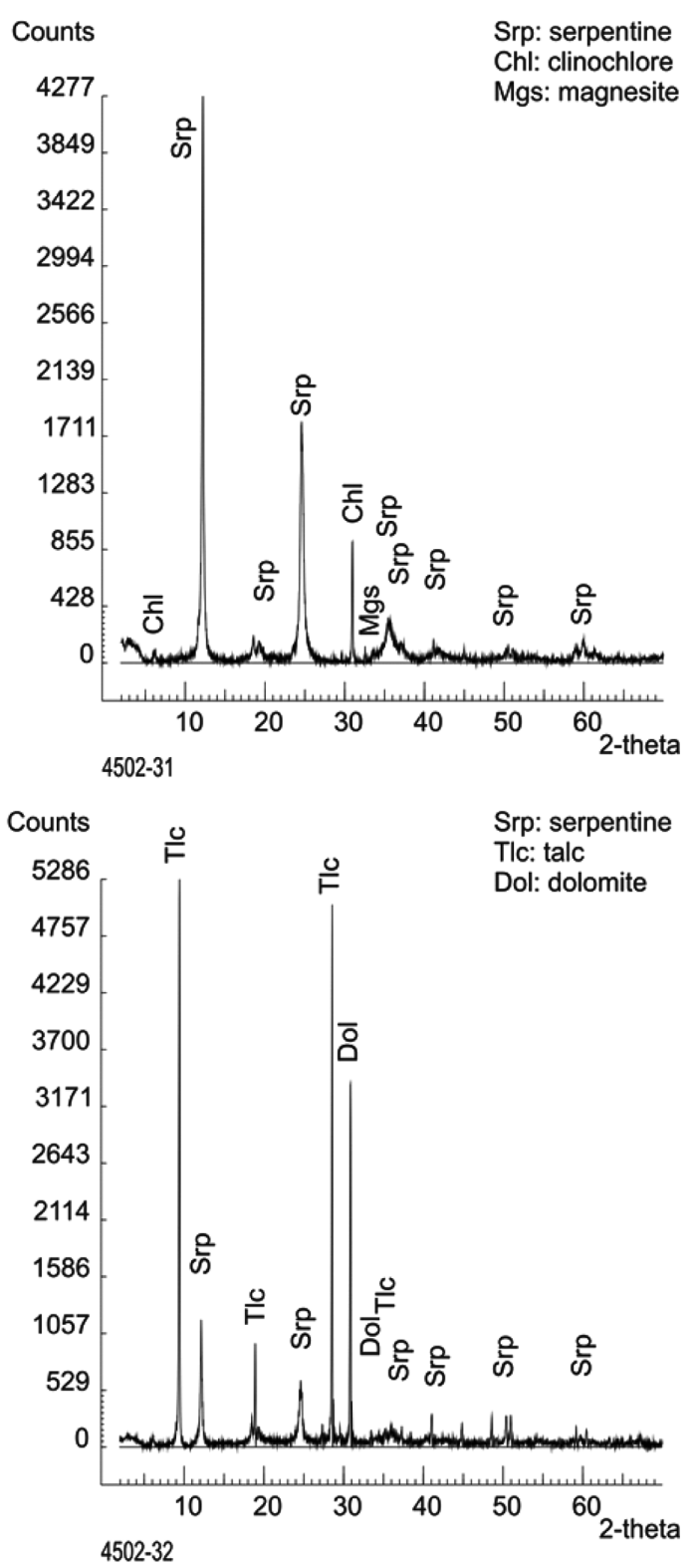

Figure 11. Diffractograms of four samples from Moeche. Through this analytical method it can be only be determined that serpentine is the most important phase, except when there is an intense alteration to talc and/or carbonate. 


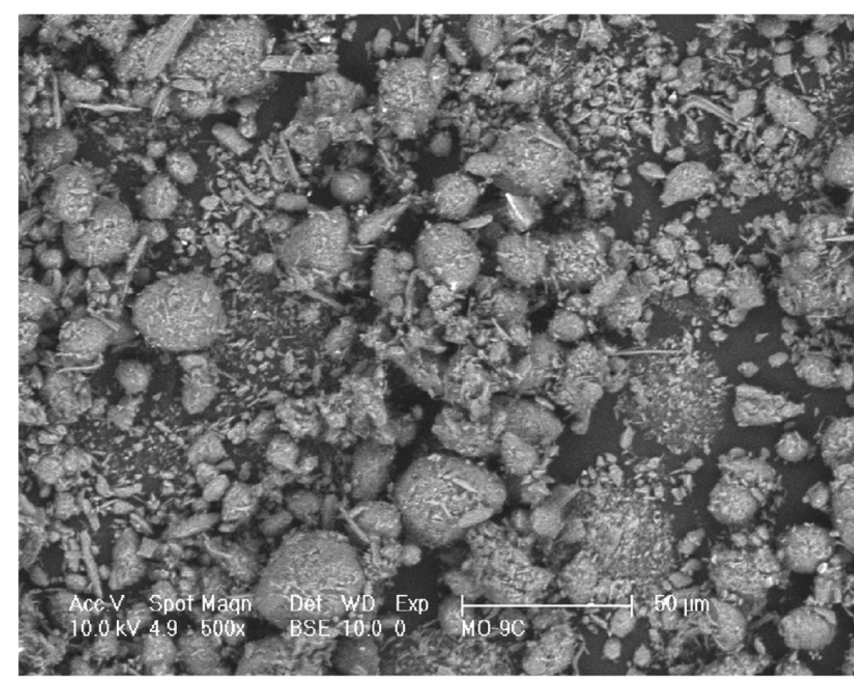

Figure 12. Scanning Electron Microprobe microphotograph in one of the selected Moeche samples, where few fibres, in contrast to the platy and globular shapes, can be distinguished.

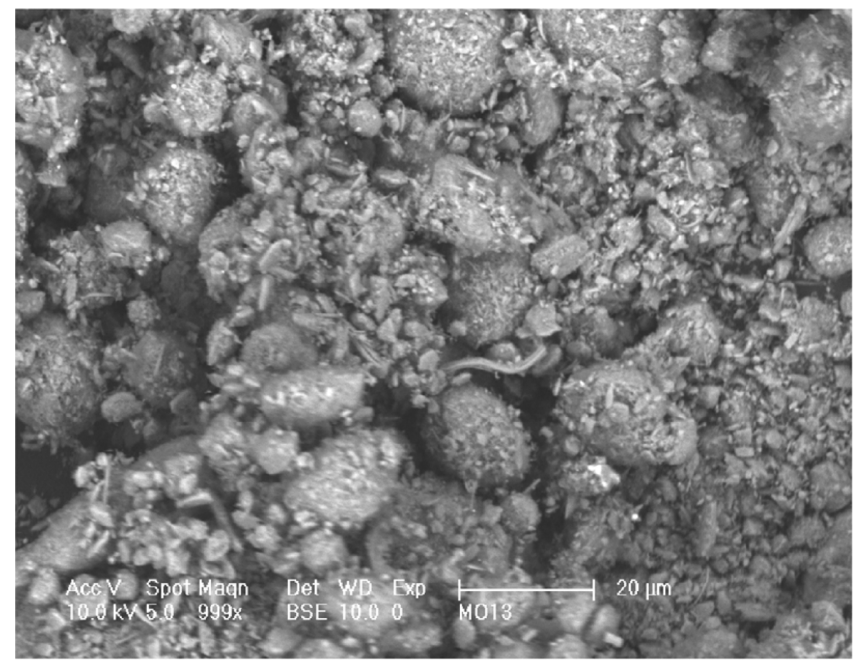

Figure 13. Scanning Electron Microprobe microphotograph in one of the selected Moeche samples, where few fibres, in contrast to the platy and globular shapes, can be distinguished.

Few particles with acicular shapes observed in the micrographs were assigned to chrysotile (Cressy and Whittaker, 1993) (Figs. 12 and 13).

\section{Discussion and Conclusions}

Because of the increasing concern on environmental and health issues derived from the use of materials containing asbestos, a specific study on serpentinites from Galicia, Spain, focused on the asbestos content of these rocks as a preliminary step for the potential reopening of the quarrying activities.

Creating a false alarm in society could generate an unnecessary stress of the population and also an adverse impact on the stone sector, mainly on local economy. It is useful to distinguish among the different fibrous minerals present in serpentinites. When referring to asbestos, the whole group of fibrous minerals (i.e., fibrous amphiboles and chrysotile) are included. However, several authors have described the different behaviour of the fibres, related to their flexibility (e.g., chrysotile is flexible, while amphibole is rigid) and their potential health influence (Feininger, 2009). It has to be taken into account that many countries have banned the use of chrysotile, but some non-European countries are still using it as a non-friable material and therefore traditional producers are still commercializing chrysotile, as encapsulated in a resin or cement.

Today normative is more restrictive, but before, Spanish/European laws concerning asbestos clearly distinguished between the allowed content for exposition to fibres: 0.6 fibres $/ \mathrm{cm}^{3}$ in the case of chrysotile and 0.3 fibres $/ \mathrm{cm}^{3}$ in the case of amphiboles. Nowadays, the limit is homogeneous for any kind of fibre.

Samples of serpentinites from an abandoned quarry in Galicia were studied to distinguish the different mineral polymorphs of serpentine they contained and to consider the viability of its opening based on the asbestos content of the rocks. Petrography, SEM and XRD of the studied samples confirm that the main mineral phase in the rocks was antigorite. The content of lizardite was scarce. Preliminary results indicated that fibrous minerals (chrysotile) were present in all the samples but only traces of these phases were detected under the petrographic microscope. The quantity was so small that X-Ray diffraction did not detect this phase. Some of the serpentinites were also transformed into carbonates, which should be taken into account if reopening of the quarry takes place. Carbonated stones should have restrictions in use if they are meant to be in contact with acidic products, as all carbonated ornamental stones. But this issue is only related to the commercialisation of the stones, as studied in Navarro et al. (2013, 2018).

The scarce amount of fibrous phases points out that the reopening of serpentinites quarries should not give health problems to the workers. However, the high heterogeneity of these rocks leads us to advice to implement a very frequent control of chrysotile in the atmosphere if the activity is reopened. Although some authors (Cattaneo et al., 2012; Berstein et al., 2013; Cavallo and Rimoldi, 2013) have indicated that the level of airborne asbestos concentration in serpentinite quarries and processing plants do not have negative effects for health at low exposure, the exposure limits should be controlled even when asbestos is present at very low levels. Prevention is the most important step in a risk analysis; the continuous control would allow to avoid health risks derived from long-time exposure, if accompanied by protection measures for the workers. The implementation of personal protective equipment, health surveillance plans and measures for dust control and remediation systems must be mandatory if the quarry activities re-start (Punturo et al., 2019).

\section{Acknowledgements}

This paper was improved with the help of the reviews of Dr Laura Gaggero and an anonymous reviewer. The University of Salamanca is acknowledged for the funding support to the Research Group CHARROCK.

\section{References}

Arenas, R., Sánchez-Martínez, S., Castiñeiras, P., Jeffries, T.E., DíezFernández, R. and Andonaegui, P., 2009, The basal tectonic mélange of 
the Cabo Ortegal Complex (NW Iberian Massif): a key unit in the suture of Pangea. Journal of Iberian Geology v. 35, pp. 85-125.

Auzende, A.L., Devouard, B., S., Danile, I., Baronnet, A. and Lardeaux, J.M., 2002, Serpentines from Central Cuba: petrology and HRTEM study. European Journal of Mineralogy, v. 14, 905-914. doi: 10.1127/ 0935-1221/2002/0014-0905

Bernstein, D.M., 2009, Review of the differences between chrysotile and amphibole asbestos. https://chrysotileassociation.com/data/encart_an_final.pdf [accessed 21th September 2019].

Bloise, A., Critelli, T., Catalano, M., Apollaro, C., Miriello, D., Croce, A., Barrese, E., Liberi, F., Piluso, E., Rinaudo, C., and Belluso, E., 2014, Asbestos and other fibrous minerals contained in the serpentinites of the Gimigliano-Mount Reventino Unit (Calabria, S-Italy). Environmental Earth Sciences, v. 71, pp. 3773-3786. doi: 10.1007/s12665-013-3035-2

Bloise, A., Catalano, M., Critelli, T., Apollaro, C. and Miriello, D. 2017, Naturally occurring asbestos: Potential for human exposure, San Severino Lucano (Basilicata, Southern Italy). Environmental Earth Sciences, v. 76. doi: 10.1007/s12665-017-6995-9.

Burgoa Fernández, J.J., 2000, El patrimonio etnográfico y el arte popular: cruceros y petos de ánimas de los municipios de Moeche y San Sadurniño. Anuario Brigantino, v. 3, pp. 477-494

Cattaneo, A., Somigliana, A., Gemmi, M., Bernabeo, F., Savoca, D., Cavallo, D.M., Cavallo, A. and Rimoldi, B., 2012, Chrysotile asbestos in serpentinite quarries: a case study in Valmalenco, Central Alps, Northern Italy. Environmental Science: Processes and Impacts, v. 15, pp. 1341-1350. doi: $10.1039 / \mathrm{C} 3 \mathrm{EM} 00193 \mathrm{H}$

Cavallo, A. and Rimoldi, B., 2013, Chrysotile asbestos in serpentinite quarries: A case study in Valmalenco, Central Alps, Northern Italy. Environmental Science: Processes and Impacts, v. 15, pp. 1341-1350. doi: 10.1039/C3EM00193H

Cressey, B.A., and Whittaker, E.J.W., 1993, Five-fold symmetry in chrysotile asbestos revealed by transmission electron microscopy. Mineralogical magazine v. 5, pp. 729-732. doi: 10.1180/minmag.1993.057.389.17

European Commission Council Directive 76/769/EEC of 27 July 1976 on the approximation of the laws, regulations and administrative provisions of the Member States relating to restrictions on the marketing and use of certain dangerous substances and preparations. https://eur-lex.europa. eu/legal-content/EN/ALL/?uri=CELEX\%3A31976L0769 [accessed 11th October 2019].

European Commission Directive 1999/77/EC of 26 July 1999 adapting to technical progress for the sixth time Annex I to Council Directive 76/769/ EEC on the approximation of the laws, regulations and administrative provisions of the Member States relating to restrictions on the marketing and use of certain dangerous substances and preparations (asbestos). https:// eur-lex.europa.eu/legal-content/En/TXT/?uri=CELEX\%3A31999L0077 [accessed 11th October 2019].

European Commission Directive 2003/18/EC of the European Parliament and of the Council of 27 March 2003 amending Council Directive 83/ $477 / \mathrm{EEC}$ on the protection of workers from the risk related to exposure to asbestos at work. https://eur-lex.europa.eu/legal-content/EN/ALL/ ?uri=CELEX:32003L0018 [accessed 11th October 2019].

Feininger, T., 2009, Why study mineralogy? Elements, v. 209, pp. 196.

Gaggero, L., Crispini, L., Isola, E., and Marescotti, P., 2013, Asbestos in natural and anthropic ophiolitic environments: A case study of geohazards related to the Northern Apennine ophiolites (Eastern Liguria, Italy). Ofioliti, v. 38, pp. 29-40. doi: 10.4454/ofioliti.v38i1.414.

Instituto Nacional de Seguridad e Higiene en el Trabajo (INSHT), 2008, Guía Técnica para la evaluación y prevención de los riesgos relacionados con la exposición al amianto. Ministerio de Trabajo e Inmigración, Baracaldo (Vizcaya), 93 p.

International Agency for Research on Cancer (IARC), 2012, Asbestos (Chrysotile, Amosite, Crocidolite, Tremolite, Actinolite and anthophylite). In: Arsenic, Metals, Fibres and Dusts. A review of human Carcinogens. International Agency for Research on Cancer Monographs, Lyon (France), 100C, pp. 219-309.
López-Buendía, A.M., Guillem, C., Cuevas, J.M., Mateos, F., and Montoto, M., 2013, Natural stone reinforcement of discontinuities with resin for industrial processing. Engineering Geology, v. 166, pp. 39-51. doi: 10.1016/j.enggeo.2013.09.004

Martínez-Catalán, J.R., Gómez-Barreiro-J., Dias da Silva, M., Chichorro, M., López-Carmona, A., Castiñeiras, P., Abati, J., Andonaegui, P., Fernández-Suárez, J., González-Cuadra, P., and Benítez-Pérez, J.M., 2019, Variscan Suture Zone and Suspect Terranes in the NW Iberian Massif: Allochthonous Complexes of the Galicia-Trás os Montes Zone (NW Iberia), in: Quesada, C. and Oliveira, J.T. (Eds.), The Geology of Iberia: A Geodynamic Approach. Volume 2: The Variscan Cycle. Springer Nature, Switzerland, pp. 99-130.

National Health Service (NHS) Inform, 2017, Asbestosis symptoms and treatments. https://www.nhs.uk/conditions/asbestosis/ [accessed: $28^{\text {th }}$ November 2019].

National Institute for Occupational Safety and Health (NIOSH), 2008, Asbestos and Other Elongated Mineral Particles: State of the Science and Roadmap for Research. National Institute for Occupational Safety and Health (NIOSH): Washington, DC, USA, 142 p.

Natural Stone Institute, 2014, Granite, Radon, Radiation and Other Myths. https://www.naturalstoneinstitute.org/consumers/radon/. [Accessed $1^{\text {st }}$ October 2019].

Navarro, R., Pereira, D., Gimeno, A., and del Barrio, S., 2013, Verde Macael: A serpentinite wrongly referred to as a marble. Geosciences, v. 3, pp. 102-113. doi: 10.3390/geosciences3010102

Navarro, R., Pereira, D., Gimeno, A., and del Barrio, S., 2018, Influence of natural carbonation process in serpentinites used as construction and building materials. Construction and Building Materials, v. 170, pp. 537-546. doi: 10.1016/j.conbuildmat.2018.03.100

Nespereira, J., Navarro, R., Monterrubiop, S., Yenes, M., and Pereira, D., 2019, Serpentinite from Moeche (Galicia, north western Spain). A stone used for centuries in the construction of the architectural heritage of the region. Sustainability, v. 11, doi: 10.3390/su11092700

Pereira, D., Blanco, J.A., Yenes, M., and Peinado, M., 2005, Las serpentinitas y su correcta utilización en construcción. Roc Maquina., v. 9, pp. 24-27.

Pereira, D., Yenes, M., Blanco, J.A. and Peinado, M., 2007, Characterization of serpentinites to define their appropriate use as dimension stone, in: Prikryl, R. and Smith, B.J. (Eds.), Building Stone Decay: From Diagnosis to Conservation, Geological Society of London, Special Publication, 271, pp. 55-62. doi: 10.1144/GSL.SP.2007.271.01.06

Pereira, D., 2012, A report on serpentinites in the context of heritage stone resources, Episodes, v. 35, pp. 478-480. doi: 10.18814/epiiugs/2012/ v35i4/003

Pereira, D., Peinado, M., and Blanco, J.A., 2013, Misuse of natural stone for construction and the consequences in buildings. Case of study of serpentinites. Journal of Materials in Civil Engineering, v. 25, pp. 1563-1567. doi: 10.1061/(ASCE)MT.1943-5533.0000689

Pereira, D., Peinado, M., Yenes, M., Monterrubio, S., Nespereira, J. and Blanco, J.A., 2010, Serpentinites from Cabo Ortegal (Galicia, Spain): a search for correct use as ornamental stones. Geological Society of London, Special publication, 333, pp. 81-85. doi: 10.1144/SP333.8

Pereira, D., Peinado, M., Blanco, J.A. and Yenes, M., 2008, Geochemical characterization of a serpentinization process at Cabo Ortegal (NW Spain). The Canadian Mineralogist, v. 46, pp. 317-327. doi: 10.3749/canmin. 46.2.317

Pereira, D., Neves, L., Pereira, A., and González-Neila, C., 2011, Natural radioactivity in ornamental stones: an approach for its study in known samples from Iberia. Bulletin of Engineering and the Environment v. 70, pp. 543-547. doi: 10.1007/s10064-011-0389-0

Pereira, D., Blanco, J.A., and Peinado, M., 2013, Study on Serpentinites and the Consequence of the Misuse of Natural Stone in Buildings for Construction. Journal of Materials in Civil Engineering, v. 25, pp. 1563-1567. doi: 10.1061/(ASCE)MT.1943-5533.0000689

Punturo, R., Ricchiuti, C., Rizzo, M., and Marrocchin, E., 2019, Miner- 
alogical and Microstructural Features of Namibia Marbles: Insights about Tremolite Related to Natural Asbestos Occurrences. Fibres, v. 7. doi: 10.3390/fib7040031

Rivero Crespo, M.A., Pereira Gómez, D., Villa García, M.V., Gallardo Amores, J.M., and Sánchez Escribano, V., 2019, Characterization of Serpentines from Different Regions by Transmission Electron Microscopy, X-ray Diffraction, BET Specific Surface Area and Vibrational and Electronic Spectroscopy. Fibres v. 7. doi: 10.3390/fib7050047

Real Decreto 396/2006, de 31 de marzo, por el que se establecen las disposiciones mínimas de seguridad y salud aplicables a los trabajos con riesgo de exposición al amianto. Ministerio de la Presidencia. https:// www.boe.es/eli/es/rd/2006/03/31/396/con [accessed 11th October 2019]

Sporn, T.A., Roggli, V.L., and Oury, T.D., (Eds.), 2004, Pathology of asbestos-

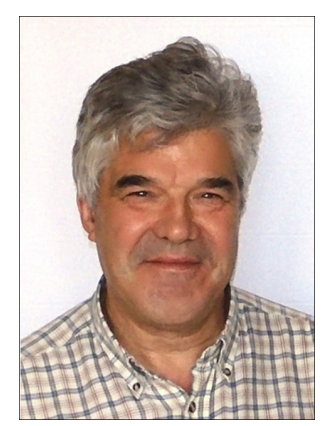

Serafín Monterrubio is a Senior Lecturer in geology at Zamora Polytechnic School, Salamanca University. His research is related to applied mineralogy,subject of his $\mathrm{PhD}$, and applied geology and geotechnics, subjects he currently teaches.

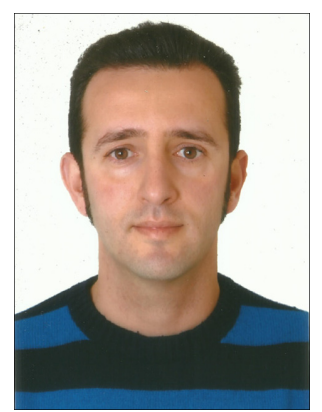

Rafael Navarro is a $\mathrm{PhD}$ in geology, with more than twenty years of experience in mining exploration, mainly for private companies. He has focused his research activity in all related with industrial rocks and minerals, especially in dimension stones. He is also member of the research group CHARROCK of the University of Salamanca (Spain). associated diseases. Springer, Berlin, 357 p. doi: 10.1007/978-3-64241193-9

Wicks, F.J., and O'Hanley, D.S., 1988, Serpentine Mineral: Structure and petrology. Reviews in Mineralogy. In: Baley, S.W. (Ed), Mineralogical society of America, Chantilly VA, USA, pp. 91-167.

Wicks, F.J., and Whittaker, E.J.W., 1977, Serpentine textures and serpentinization. Canadian Mineralogist, v. 15, pp. 459-488.

Wicks, F.J., Whittaker, E.J.W. and Zussman, J., 1977, An idealized model for serpentine textures after olivine. Canadian Mineralogist, v. 15, pp. 446-458.

World Health Organization (WHO), 1986, Asbestos and Other Natural Mineral Fibres. World Health Organization, Geneva, Switzerland, 194 p.

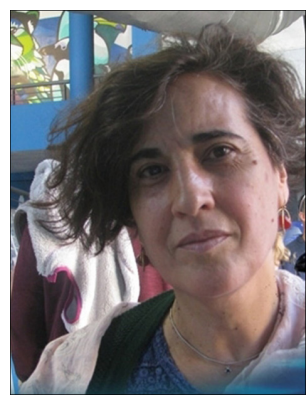

Dolores Pereira is professor of Geology and Engineering Geology at the University of Salamanca. She teaches as well at the Master of Social Studies for Science and Technology of this university. She is secretary general of the IUGS Heritage Stones Subcommission and Chair of the IUGS Publications Committee. Her research interests include natural stones from their chemical, mineralogical, hazardsrelated matters and physic-mechanical characterization point of view as well as their use in new building and restoration of architectural heritage. 